\section{NIH inquiry fails to find culprit of contamination}

[WASHINGTON] The US National Institutes of Health (NIH) are not to be stripped of their licence to use nuclear materials, despite the efforts of a pregnant scientist who was contaminated with radioactive phosphorus while working there (see Nature 377, 568; 1995).

The Nuclear Regulatory Commission (NRC) has denied a petition from Maryann Wenli Ma and her husband, Bill Wenling Zheng, that NIH's licence to use nuclear materials be revoked or suspended.

After the discovery of Ma's exposure in June 1995, it was found that 26 others including Zheng — had been exposed to radiation from a contaminated water cooler at NIH (but not through the consumption of Chinese food that had been left in a refrigerator, as originally thought).

Investigators from the NRC, working jointly with the Federal Bureau of Investigation and the NIH police, concluded that the contamination was "deliberate", but could not identify the perpetrator.

The NRC said in a statement that, normally, "radiation overexposures of this sort would be subject to significant enforcement action". But it added that it would exercise discretion in this case because there was no evidence that NIH had contributed directly or indirectly to the deliberate misuse of licensed material.

Also, NIH "could not reasonably have foreseen" malicious misuse of materials by an employee, and had cooperated fully in the investigation.

The NRC did say, however, that NIH had violated several requirements for the security and control of radioactive materials, but that the agency had since made "significant efforts to improve its control".

David Marshall, a lawyer representing $\mathrm{Ma}$ and Zheng, says that the decision "allows the $[\mathrm{NIH}]$ to continue to put its employees and the public at risk with impunity". The lawyers are considering filing a civil suit for damages in the federal court. Although Ma's son David was born apparently healthy, "Dr $\mathrm{Ma}$ and her child will live for years with the dangerous and uncertain effects of radiation poisoning", says Marshall.

The NIH has issued a statement welcoming the NRC conclusion. "It is particularly significant," it said, that the NRC found the contamination "was not the result of faulty compliance with security requirements for radioactive materials".

But the statement also pointed out that NIH had nevertheless "consistently tightened its standards for the security and use of such materials".

MeredithWadman

\title{
UK nuclear waste company gets extended lease of life
}

[LONDON] Britain's embattled nuclear waste disposal company Nirex has been given a one-year lease of life under a new part-time chairman, quashing speculation that it was on the verge of being wound up or merged with one of its shareholder companies.

A meeting of the Nirex board last week agreed to keep the company intact with no further job losses for the next 12 months and to maintain its $\mathfrak{} 30$ million (US\$49 million) annual research budget. A final decision on Nirex's future will now depend on the new government's yet-to-be-announced plans for disposing of nearly 300,000 cubic metres of radioactive waste from nuclear power plants.

Speculation had been mounting before the meeting that Nirex was to merge with its largest shareholder, British Nuclear Fuels (BNFL), which owns 40 per cent of Nirex.

But the board chose to bring the two closer together by appointing David Bonser, BNFL's director of waste management and decommissioning, as Nirex's new chairman.

The company's future was put in doubt last April (see Nature 386, 423-424; 1997) after the previous government blocked its plans to dispose of nuclear waste at a proposed underground repository at Sellafield in north-west England. Nirex had spent

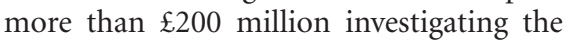
site. The choice of Sellafield had been opposed by the local authority and environmentalist groups, which also agree that waste must be retrievable.

With no immediate prospect of an alternative site to investigate, Nirex had little choice but to begin a rapid programme of retrenchment, and shed more than half of its 200 staff, including many scientists. Some believed that cuts would continue. But in a statement, Bonser said that he looked forward to "building for the future on [Nirex's] scientific excellence".

Environmentalist groups have reacted coolly to the appointment, arguing that it suggests a 'business as usual' approach in an agency that has come under fire for its secrecy and for the perceived lack of public involvement in its decision to choose Sellafield. Helen Wallace, a senior scientist with Greenpeace, says Bonser's appointment will only reinforce such an impression. "Nirex is not going to gain any public support by appointing a nuclear industry insider."

But one former government adviser on radioactive waste policy, while accepting that the choice of chairman "is not a step that will create public confidence", says that the one-year moratorium on further changes and the appointment of a part-time chairman suggests that the nuclear industry wants to keep a watching brief over Nirex while giving the new government flexibility in planning for the future.

If it chose to do so, the government could still retain Nirex as the agency responsible for radioactive waste disposal, he says. But the board's decision does not foreclose the other option - preferred by environmentalist groups - of setting up a new, independent and publicly accountable agency.

EhsanMasood

\section{'Government should decide on disposal site'}

[LONDON] Nirex, Britain's nuclear waste disposal agency, has made clear that it does not want

responsibility for choosing a new waste-disposal site even if the government decides that it should retain its independence.

According to John Holmes, Nirex's director of technical services, the government and not Nirex should take the lead in any future site-selection process; and, once a decision is made, it should be protected from politically motivated interference.

Nirex took much of the blame for the choice of the
Sellafield site, even though the decision is believed to have been fully endorsed by the late Nicholas Ridley, environment secretary in the then Conservative government, only to be overturned by his successor, John Gummer.

Holmes was speaking last month at a discussion organized by the Geological Society of London on the future of radioactive waste disposal in Britain. He acknowledged that Nirex had made mistakes, by, for example, not discussing its plans with more scientists outside the company.

Despite planning for a sealed underground repository, one Nirex official has revealed that Nirex's eventual choice of repository would have had a degree of retrievability almost by default.

The safest, but most expensive and least retrievable, option would have been to build a deep repository that would be filled with concrete every time waste was placed at weekly or monthly intervals. A cheaper, more retrievable method would have been to fill a repository with concrete only when it was full of waste. "Nirex was tending towards this option," he says.

E.M. 